\title{
HLA Class II (DRB1 and DQB1) Polymorphism in Omanis
}

\author{
Khalid Rashid Albalushi ${ }^{1,2}$, Mohamed Hichem Sellami ${ }^{3}$, Hamad AIRiyami ${ }^{2}$, Mathew Varghese ${ }^{2}$, Mohamed Kamel Boukef ${ }^{1}$ and Slama Hmida ${ }^{1,3}$ \\ ${ }^{1}$ Faculty of Pharmacy, University of Monastir, Tunisia \\ ${ }^{2}$ Department of Genetics, Sultan Qaboos University, Sultanate of Oman \\ ${ }^{3}$ Department of Immunohaematology, National Blood Transfusion Centre of Tunis, Tunisia
}

"Corresponding author: Mohamed Hichem Sellami, Department of Immuno-Haematology, The National Blood Transfusion Centre of Tunis, 13 Rue Djbel Lakhdar-Bab Saadoun 1006; Tunis-Tunisia, Tel: +216 71.561.920, +216 71.573.884; Fax: + 216 71.562.957; E-mail: mohamedhichem.sellami@rns.tn

Rec date: Jun 13, 2014, Acc date: Jul 25, 2014, Pub date: Jul 27, 2014

Copyright: (c) 2014 Albalushi KR, et al. This is an open-access article distributed under the terms of the Creative Commons Attribution License, which permits unrestricted use, distribution, and reproduction in any medium, provided the original author and source are credited.

\begin{abstract}
The HLA class II polymorphism of 254 healthy unrelated Omanis was analyzed by PCR-SSP method, and the detected frequencies were compared to those reported in 20 other populations. The most frequent HLA class II DRB1 alleles were DRB1* 16 , DRB $1{ }^{*} 03$ and DRB $1{ }^{*} 15$ with frequencies of $0.315,0.224$ and 0.106 respectively, while the most frequent DQB1 alleles were DQB ${ }^{*} 05$ and $\mathrm{DQB} 1{ }^{*} 02$ with frequencies of 0.366 and 0.283 respectively. The haplotype analysis revealed that $\mathrm{DRB} 1^{*} 03-\mathrm{DQB} 1{ }^{*} 02$ was the most common HLA class II haplotype with linkage disequilibrium (a frequency of 0.206 ). Compared with other populations, our result, deduced from the analysis of genetic distances and the construction of neighbour joining dendrogram, indicates that Omanis are related to Mediterranean and West-Asian populations. This fact might be explained by several historic and socio-geographic factors if we consider on the long history of this population.
\end{abstract}

Keywords: HLA class II; Linkage disequilibrium; Polymorphism; Omanis

\section{Introduction}

The HLA system is the most polymorphic genetic system described in humans and consists of several closely linked loci [1-4]. All HLA loci map to the short arm of chromosome 6 (6.p21) and were classified in two major HLA classes: class I (A, -B, -C, -E, -F, -G and -H) and class II (DRA, -DRB, -DQA1, -DQB1, -DPA1, -DPB1, -DMA, -DMB, DOA and -DOB) $[1,5]$. Others non-HLA genes and pseudogenes have been also reported of which some loci were grouped in a third HLA class (HLA class III) [1]. More than 9,000 alleles characterising HLA polymorphism have been documented in the IMGT/HLA database (release 3.9.0) of which 1,122 alleles (14.3\%) were described in the most recent common and well-documented HLA alleles catalogue [6]. The high degree of polymorphism of the HLA system has proved a useful tool in tracing the migration of ancient human populations as well as studying the ethnic composition of the present day populations $[7,8]$. Thus, it had been reported that some HLA alleles and haplotypes are frequent only in specific populations due to several social and historic factors [9].

Oman is an Arabic country occupying the south eastern corner of the Arabian Peninsula. The History of Oman is very rich due to its strategic position on the borders of the Indian Ocean area and the Arabian Gulf. As reported by Paul Lunde in "Oman: A history", the coast of Oman was occupied by Persians early in its history [10]. The Persian control was extended for 10 centuries until the arrival of Islam (from 3rd century BC to 7th century AD) and exerted by two other Iranian dynasties, the Parthians and the Sassanids. Oman territories have also experienced the arrival of tribes from Marib (Yemen) during the pre-Islamic time in a strategy to control the lucrative incense trade [11]. With the advent of Islam, the Omani population was enriched with other tribes [10]. Thus, it is clear that Omanis were in regular contact with other ethnic groups during all ages and that this has led to the genetic heterogeneity of this population.

Studying HLA polymorphism in various populations can enrich the international HLA database which is very useful in clinical practices and in anthropological studies [5]. Thus, we decided to conduct this basic genetic study in order to investigate the HLA class II system polymorphism in Omani population which is an Arabic population occupying the south eastern corner of the Arabian Peninsula.

To date, few studies investigating the HLA polymorphism in Omanis have been published [12-14]. Here we present a study of HLA Class II polymorphism of Omanis using a molecular approach.

\section{Materials and Methods}

Informed consent was obtained from all participants, and approval was obtained from the ethical committee for scientific and medical research of the College of Medicine and Health Sciences at Sultan Qaboos University (Sultanate of Oman) for performing this study.

Study subjects: A total of 254 healthy and unrelated normal blood donors (149 men and 105 women) were randomly selected from the Omani population (from all regions of the Sultanate) to perform this study. The origin of the other populations used for the interethnic comparison is detailed in (Table 1) [15].

\begin{tabular}{|l|l|}
\hline Population & Sample size \\
\hline Omanis - currentstudy & 254 \\
\hline Iran.Azeri & 100 \\
\hline Iran.Baloch & 100 \\
\hline Iran.Kurd & 100 \\
\hline Ashkenazi.Jews.pop2 & 132 \\
\hline
\end{tabular}


Page 2 of 6

\begin{tabular}{|l|l|}
\hline Gaza.Palestinian & 165 \\
\hline Iranian.Jews & 101 \\
\hline Lebanon.pop.2 & 191 \\
\hline India.Uttar.Pradesh & 202 \\
\hline Algeria.pop.2 & 106 \\
\hline Ethiopia.Amhara & 98 \\
\hline Ethiopia.Oromo & 83 \\
\hline Morocco & 96 \\
\hline Tunisia.Jerba.Berber & 55 \\
\hline Tunisia.Matmata.Berber & 81 \\
\hline Tunisia.pop.3 & 104 \\
\hline Turkey.pop.2 & 228 \\
\hline Bangladesh.Dhaka.Bangalee & 141 \\
\hline Pakistan.Baloch & 66 \\
\hline Pakistan.Brahui & 104 \\
\hline Pakistan.Karachi.Parsi & 91 \\
\hline
\end{tabular}

Statistical analysis: HLA-DRB1/DQB1 allele and haplotype frequencies; Hardy-Weinberg equilibrium for each locus; and relative linkage disequilibrium (D') between these loci were calculated by applying the expectation-maximization (EM) algorithm (Arlequin program V3.5.12) [16]. Standard deviations (SD), for both alleles and haplotypes frequencies (HF), were obtained by a bootstrap procedure $[16]$.

Omani HLA-DRB1 and -DQB1 allele frequencies were compared with other Mediterranean and Asian population's frequencies in order to investigate the relatedness between these populations. In this analysis, we used only HLA-DRB1 allele frequencies because some of the populations used lacked some HLA-DQB1 data. Phylogenetic tree (dendrogram) was constructed with allele frequencies by applying the Neighbor-Joining (NJ) method with the standard genetic distances (SGD) [17,18], using the Dispan software which contains the GNKDST and TREEVIEW application [19,20].

\section{Results}

Hardy-Weinberg test analysis showed that all alleles at the DRB1 and DQB1 loci are in equilibrium ( $\mathrm{p}$ values are, respectively, 0.27 and $0.13)$.

HLA class II allele frequencies: The allele analysis showed the presence of 11 variants at the HLA-DRB1 locus of which DRB1*16 and $D R B 1^{\star} 03$ were the most frequent in Omanis (Table 2). Except the $\mathrm{DRB} 1^{\star} 03$ allele which is frequent in all populations, $\mathrm{DRB} 1^{\star} 16$ variant is a common allele among the Southeast Asian peoples such as in Malaysia (28\%), Papua New guinea (28\%) and Vietnam (19.2\%) and in South American peoples such as in Brazil (37\%), Colombia (38\%), Mexico (30.9\%) [15]. The third frequent HLA-DRB1 allele in Omanis was the $\mathrm{DRB} 1^{\star} 15$ which is a common allele between several ethnic groups [15]. manufacturer's specifications (Dynal Allset Gold SSP, Life Technologies Corp).

\begin{tabular}{|l|l|l|l|l|l|l|l|}
\hline DRB1 locus & $\begin{array}{l}\text { No. subjects } \\
\text { with allele }\end{array}$ & $\begin{array}{l}\text { Allele } \\
\text { frequency }\end{array}$ & S.D.1 & DQB1 locus & $\begin{array}{l}\text { No. subjects } \\
\text { with allele }\end{array}$ & Allele frequency & S.D. \\
\hline DRB1*01 & 2 & 0.004 & 0.003 & DQB1*02 & 138 & 0.283 & 0.019 \\
\hline DRB1*03 & 112 & 0.224 & 0.018 & DQB1*03 & 78 & 0.163 & 0.015 \\
\hline DRB1*04 & 47 & 0.096 & 0.013 & DQB1*04 & 13 & 0.026 & 0.007 \\
\hline DRB1*07 & 34 & 0.067 & 0.011 & DQB1*05 & 164 & 0.366 & 0.161 \\
\hline DRB1*09 & 2 & 0.004 & 0.003 & DQB1*06 & 76 & & 0.021 \\
\hline DRB1*11 & 40 & 0.083 & 0.012 & & & & 0.016 \\
\hline DRB1*12 & 5 & 0.01 & 0.004 & & & & \\
\hline DRB1*13 & 32 & 0.063 & 0.011 & & & & \\
\hline DRB1*14 & 14 & 0.028 & 0.007 & & & & \\
\hline DRB1*15 & 52 & 0.106 & 0.013 & & & & \\
\hline DRB1*16 & 148 & 0.315 & 0.021 & & & & \\
\hline 1: Standard deviation & & & & & & \\
\hline
\end{tabular}

Table 2: HLA-DRB1 and -DQB1 allele frequencies in the Omani population.

For the HLA-DQB1 locus, 5 alleles were detected in which $\mathrm{DQB} 1^{\star} 05$ and $\mathrm{DQB} 1^{\star} 02$ are the most frequent alleles in Omanis
(Table 2). HLA-DQB1 ${ }^{\star} 05$ is a relatively frequent allele in some Southeast Asian peoples, e.g. Malaysia "pop 2" (37.1\%) and in Pakistan 
Citation: Albalushi KR, Sellami MH, AIRiyami H, Varghese M, Boukef MK, et al. (2014) HLA Class II (DRB1 and DQB1) Polymorphism in Omanis. J Transplant Technol Res 4: 134. doi:10.4172/2161-0991.1000134

Page 3 of 6

"Baloch" (34\%) whereas a very lower frequency of this allele was reported in several Amerindian peoples, e.g. Mexico, Brazil, Argentina [15]. In contrast to $\mathrm{DQB} 1^{\star} 05$, the HLA-DQB1 ${ }^{\star} 02$ is a common allele in several populations although it was detected with high frequency in some Mediterranean populations, e.g. in Spain « Arratia Valley Basque » (48\%), Israel "Libyan Jews » (33.3\%), Morocco « pop 2 » (30.6\%), France « Rennes pop $3 »(24 \%)$ and Turkey «pop $2 »(23.8 \%)$ [15].

\begin{tabular}{|c|c|}
\hline Population & HLA-DRB1 (SGD) \\
\hline Pakistan.Brahui & 0.158 \\
\hline Pakistan.Baloch & 0.233 \\
\hline Tunisia.pop3 & 0.328 \\
\hline Iran.Baloch & 0.384 \\
\hline Iran.Kurd & 0.424 \\
\hline Algeria.pop2 & 0.467 \\
\hline Iran.Azeri & 0.52 \\
\hline Tunisia.Matmata.Berber & 0.569 \\
\hline Gaza.Palestinian & 0.574 \\
\hline Morocco & 0.618 \\
\hline Ashkenazi.Jews.pop2 & 0.629 \\
\hline Lebanon.pop2 & 0.656 \\
\hline Ethiopia.Oromo & 0.671 \\
\hline India.Uttar.Pradesh & 0.676 \\
\hline Turkey.pop2 & 0.68 \\
\hline Pakistan.Karachi.Parsi & 0.751 \\
\hline Bangladesh.Dhaka.Bangalee & 0.805 \\
\hline Ethiopia.Amhara & 0.805 \\
\hline Tunisia.Jerba.Berber & 0.848 \\
\hline Iranian.Jews & 0.885 \\
\hline
\end{tabular}

Table 3: Standard genetic distances (SGD) between Omanis and 20 other populations.

The phylogenetic analysis showed that Omanis are closer to WestAsian and Mediterranean peoples (Figure 1) than to others populations, which was more evident in (Table 3), reporting SGD between the selected populations.

HLA-DRB1-DQB1 haplotype frequencies and linkage disequilibria: The most dominant HLA-DRB1_DQB1 haplotypes in Omanis are $\mathrm{DRB}^{*} 16 \_\mathrm{DQB} 1{ }^{*} 05 \quad(\mathrm{HF} \quad 31.3 \%$, D' $0.03, \mathrm{p}>0.023)$ and $\mathrm{DRB1}^{\star} 03 \_\mathrm{DQB1} 1^{\star} 02(20.6 \%)$, but the most dominant HLA-
DRB1_DQB1 haplotype with linkage disequilibrium is the $\mathrm{DRB}^{\star}{ }^{\star} 03$ DQBB1${ }^{\star} 02$ (Table 4 ). At this level, it should be mentioned that HLA-DRB1 ${ }^{\star} 16 \_D Q B 1{ }^{\star} 05$ is found in $27.3 \%$ of Papua New Guinean peoples and in 15\% of Pakistani "Brahui"; and HLADRB1 ${ }^{\star} 03$ DQB $1{ }^{\star} 02$ is found in some Mediterranean peoples such as in Tunisians "Gabes" (15\%), Israel "Arabs " (9.6\%) and Moroccans "pop 2" (9.3\%) [15]. 
Citation: Albalushi KR, Sellami MH, AIRiyami H, Varghese M, Boukef MK, et al. (2014) HLA Class II (DRB1 and DQB1) Polymorphism in Omanis. J Transplant Technol Res 4: 134. doi:10.4172/2161-0991.1000134

Page 4 of 6

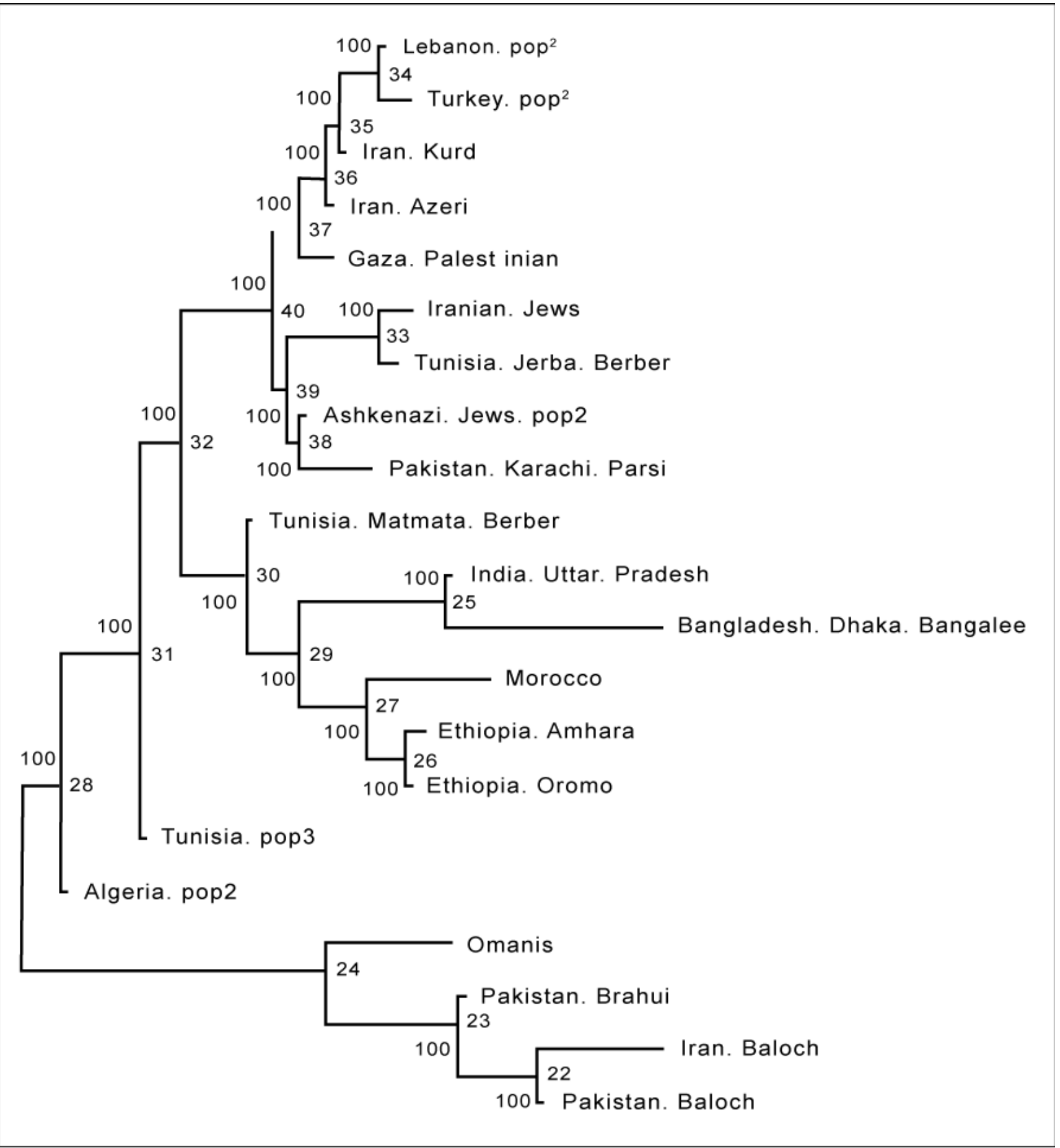

Figure 1: Neighbour-joining dendrogram showing relatedness between Omanis and some neighbouring populations. Standard genetic distances (SGD) were calculated by using HLA-DRB1 allele frequencies. Data from other populations were taken from references detailed in (Table 1). Bootstrap values from 1000 replicates are shown.

\section{Discussion}

The HLA class II allele analysis showed that the frequent HLADRB1 variants in Omanis, (Table 1) are those that are common in some Southeast Asian and Mediterranean populations especially the
HLA-DRB1*16, $-\mathrm{DRB} 1^{\star} 15$ and $-\mathrm{DRB} 1^{\star} 03$ variants [2gfgf1-24]. The same findings were also observed when analysing the HLA-DQB1 locus [22-25]. Thus, it seems likely that there is an HLA allele admixture between Omanis and Mediterranean-West Asian peoples. This finding was supported when analysing HLA class II haplotypes. 
Page 5 of 6

We revealed that the predominant haplotypes, with significant linkage disequilibrium, in Omanis, e.g. HLA-DRB1 ${ }^{\star} 03-\mathrm{DQB1} 1^{\star} 02$ is also predominant in some Mediterranean peoples such as Tunisians, Israel "Arabs" and Moroccans [22,26,27]. Accordingly, we believe that these findings provide some evidence that Omanis are close to Mediterranean and West-Asian populations. This proposal might be explained by several historic and socio-geographic factors if we consider the long history of this region [10].

\begin{tabular}{|c|c|c|c|c|c|}
\hline Haplotype & No. subjects with haplotype & Frequency & S.D.1 & D' value & $p$ value for significance of $D^{\prime}$ \\
\hline $\begin{array}{l}\text { DRB1*16- } \\
\text { DQB1*05 }\end{array}$ & 158 & 0.313 & 0.02 & 0.093 & 0.023 \\
\hline $\begin{array}{l}\text { DRB1*03- } \\
\text { DQB1*02 }\end{array}$ & 104 & 0.206 & 0.018 & 0.228 & 0.01 \\
\hline $\begin{array}{l}\text { DRB1*15- } \\
\text { DQB1*06 }\end{array}$ & 46 & 0.09 & 0.013 & 0.106 & 0.044 \\
\hline $\begin{array}{l}\text { DRB1*04- } \\
\text { DQB1*03 }\end{array}$ & 39 & 0.077 & 0.012 & 0.037 & 0.006 \\
\hline $\begin{array}{l}\text { DRB1*11- } \\
\text { DQB1*03 }\end{array}$ & 35 & 0.071 & 0.012 & 0.01 & 0.035 \\
\hline $\begin{array}{l}\text { DRB1*07- } \\
\text { DQB1*02 }\end{array}$ & 31 & 0.064 & 0.011 & 0.051 & 0.018 \\
\hline $\begin{array}{l}\text { DRB1*13- } \\
\text { DQB1*06 }\end{array}$ & 28 & 0.055 & 0.011 & 0.003 & 0.009 \\
\hline $\begin{array}{l}\text { DRB1*14- } \\
\text { DQB1*05 }\end{array}$ & 13 & 0.026 & 0.007 & 0.009 & 0.083 \\
\hline $\begin{array}{l}\text { DRB1*03- } \\
\text { DQB1*04 }\end{array}$ & 8 & 0.016 & 0.006 & 0.091 & 0.011 \\
\hline $\begin{array}{l}\text { DRB1*15- } \\
\text { DQB1*05 }\end{array}$ & 8 & 0.016 & 0.005 & 0.107 & 0.029 \\
\hline $\begin{array}{l}\text { DRB1*11- } \\
\text { DQB1*06 }\end{array}$ & 5 & 0.012 & 0.005 & 0.007 & 0.047 \\
\hline $\begin{array}{l}\text { DRB1*04- } \\
\text { DQB1*02 }\end{array}$ & 5 & 0.01 & 0.005 & 0.008 & 0.055 \\
\hline $\begin{array}{l}\text { DRB1*04- } \\
\text { DQB1*04 }\end{array}$ & 5 & 0.01 & 0.005 & 0.008 & 0.039 \\
\hline
\end{tabular}

Table 4: HLA-DRB1-DQB1 haplotype frequencies and linkage disequilibrium values (D') in the Omani population.

The possible relatedness of Omanis to Mediterranean and WestAsian populations is not surprising in view of the above cited reasons. Any genetic overlapping between Omanis and West-Asian peoples is likely to be correlated with interethnic marriages during the Persian domination of the coast of Oman early in history. The same theory may also be valid to explain the relatedness of Omanis to Mediterranean peoples and we think that some Mediterranean groups who came to Oman for trade were finally settled down in the region [10]. This possibility may be reinforced by the importance of Oman territories as an ancient economic and military area. In fact, Oman is located in a strategic region that links the ancient Fertile Crescent or "The Cradle of Civilization" to the Indian Ocean area and it is in the same time a very appropriate location to control sea incense trade routes between the Arabian Gulf, Gulf of Oman and Indian Ocean [11]. So, it is quite normal to be colonized by major forces such as Persians followed by tribes of Marib, Portuguese and Ottomans that leaded to an admixture of the Omani's genetic patrimony.
This work will help to further investigate the relatedness between Omanis and others middle east populations. Furthermore, such studies will be helpful in making an Arabic HLA allele frequency database that would prove useful in clinical practices especially in bone marrow and solid organ transplantation.

\section{Acknowledgment}

We thank all technicians from the Genetics Department at the College of Medicine and Health Sciences (Sultan Qaboos University, Sultanate of Oman) and from the National Blood Transfusion Centre of Tunis (Tunisia) for their valuable technical assistance.

\section{References}

1. Gautier AC, Gagne K, Retière C, Devys A, Bignon JD (2007) Système HLA. Encyclopédie médico-chirurgicale 13-000-M-53. 
Citation: Albalushi KR, Sellami MH, AIRiyami H, Varghese M, Boukef MK, et al. (2014) HLA Class II (DRB1 and DQB1) Polymorphism in Omanis. J Transplant Technol Res 4: 134. doi:10.4172/2161-0991.1000134

Page 6 of 6

2. Howell WM, Carter V, Clark B (2010) The HLA system: immunobiology, HLA typing, antibody screening and crossmatching techniques. J Clin Pathol 63: 387-390.

3. Poluektov YO, Kim A, Sadegh-Nasseri S (2013) HLA-DO and Its Role in MHC Class II Antigen Presentation. Front Immunol 4: 260.

4. Tsai S, Santamaria P (2013) MHC Class II Polymorphisms, Autoreactive T-Cells, and Autoimmunity. Front Immunol 4: 321.

5. Robinson J, Mistry K, McWilliam H, Lopez R, Parham P, et al. (2011) The IMGT/HLA database. Nucleic Acids Res 39: D1171-1176.

6. Mack SJ, Cano P, Hollenbach JA, He J, Hurley CK, et al. (2013) Common and well-documented HLA alleles: 2012 update to the CWD catalogue. Tissue Antigens 81: 194-203.

7. Tokunaga K, Imanishi T, Takahashi K, Juji T (1996) On the origin and dispersal of East Asian populations as viewed from HLA haplotypes. In Prehistoric Mongoloid Dispersals, Akazawa T, Szathmary E.J.E, Eds. Oxford, UK: Oxford University Press 187-197.

8. Fernandez Vina MA, Hollenbach JA, Lyke KE, Sztein MB, Maiers M, et al. (2012) Tracking human migrations by the analysis of the distribution of HLA alleles, lineages and haplotypes in closed and open populations. Philos Trans R Soc Lond B Biol Sci 367: 820-829.

9. Buhler S, Sanchez-Mazas A (2006) De l'Europe à l'Inde: structure génétique et diversité des populations de part et d'autre de leurs frontières géographiques et culturelles. Antropo 11: 249-259.

10. Paul L (1983) Oman: A History. Saudi Aramco World 34: 4-7.

11. Stewart RT (1978) A Dam at Marib. Saudi Aramco World 29: 24-29.

12. White AG, Leheny W, Kuchipudi P, Varghese M, Al Riyami H, et al. (1999) Histocompatibility antigens in Omanis: Comparison with other Gulf populations and implications for disease association. Ann Saudi Med 19: 193-196.

13. Middleton D, Williams F, Meenagh A, Daar AS, Gorodezky C, et al (2000) Analysis of the distribution of HLA-A alleles in populations from five continents. Hum Immunol 61: 1048-1052.

14. Williams F, Meenagh A, Darke C, Acosta A, Daar AS, et al. (2001) Analysis of the distribution of HLA-B alleles in populations from five continents. Hum Immunol 62: 645-650.

15. Gonzalez-Galarza FF, Christmas S, Middleton D, Jones AR (2011) Allele frequency net: a database and online repository for immune gene frequencies in worldwide populations. Nucleic Acids Res 39: D913-919.
16. Excoffier L, Lischer HE (2010) Arlequin suite ver 3.5: a new series of programs to perform population genetics analyses under Linux and Windows. Mol Ecol Resour 10: 564-567.

17. Saitou N, Nei M (1987) The neighbor-joining method: a new method for reconstructing phylogenetic trees. Mol Biol Evol 4: 406-425.

18. Nei M (1972) Genetic distances between populations. Am Nat 106: 283-291.

19. Nei M (1973) Analysis of gene diversity in subdivided populations. Proc Natl Acad Sci U S A 70: 3321-3323.

20. Nei M, Tajima Y, Tateno Y (1983) Accuracy of estimated phylogenetic trees from molecular data. J Mol Evol 19: 153-170.

21. Oumhani K, Canossi A, Piancatelli D, Di Rocco M, Del Beato T, et al. (2002) Sequence-Based analysis of the HLA-DRB1 polymorphism in Metalsa Berber and Chaouya Arabic-speaking groups from Morocco. Hum Immunol 63: 129-138.

22. Mohyuddin A, Ayub Q, Khaliq S, Mansoor A, Mazhar K, et al. (2002) HLA polymorphism in six ethnic groups from Pakistan. Tissue Antigens 59: 492-501.

23. Dhaliwal JS, Shahnaz M, Too CL, et al. (2007) HLA-A, -B and -DR allele and haplotype frequencies in Malays. Asian Pac J Allergy Immunol 25: 47-51.

24. Ali ME, Ahmed MU, Alam S, Rahman MH (2008) HLA-A, -B and DRB1 allele frequencies in the Bangladeshi population. Tissue Antigens 72: 115-119.

25. Arnaiz-Villena A, Karin M, Bendikuze N, Gomez-Casado E, Moscoso J, et al. (2001) HLA alleles and haplotypes in the Turkish population: relatedness to Kurds, Armenians and other Mediterraneans. Tissue Antigens 57: 308-317.

26. Amar A, Kwon OJ, Motro U, Witt CS, Bonne-Tamir B, et al. (1999) Molecular analysis of HLA class II polymorphisms among different ethnic groups in Israel. Hum Immunol 60: 723-730.

27. Lampis R, Morelli L, Congia M, et al. (2000) The inter-regional distribution of HLA class II haplotypes indicates the suitability of the Sardinian population for case-control association studies in complex diseases. Hum Mol Genet 9: 2959-2965. 